BASINDO : Jurnal Kajian Bahasa, Sastra Indonesia, dan Pembelajarannya

Volume 2 Nomor 1, 2018

Journal homepage : http://journal2.um.ac.id/index.php/basindo

\title{
KECENDERUNGAN PENOKOHAN DAN PENGALURAN CERPEN KARYA MAHASISWA UM DALAM MAJALAH KOMUNIKASI TAHUN TERBIT 2011-2017
}

\author{
Mimin Ernawati*, Heri Suwignyo, Roekhan \\ Universitas Negeri Malang, Indonesia
}

\begin{tabular}{|c|c|}
\hline A R T ICLE INFO & A B S T R A C T \\
\hline $\begin{array}{l}\text { Keyword: } \\
\text { penokohan, } \\
\text { pengaluran, } \\
\text { cerpen, } \\
\text { mahasiswa }\end{array}$ & $\begin{array}{l}\text { Tujuan penelitian ini untuk mendeskripsikan kecenderungan penokohan dan pengaluran } \\
\text { cerpen karya mahasiswa UM. Pendekatan kualitatif deskriptif dengan instrumen utama } \\
\text { peneliti sendiri dan instrumen pembantu berupa tabel pedoman analisis. Temuan } \\
\text { penelitian adalah: (1) cerpen dengan teknik penokohan secara langsung; (2) cerpen } \\
\text { dengan teknik penokohan secara tidak langsung; ( } 3 \text { ) cerpen dengan teknik penokohan } \\
\text { campuran; (4) cerpen dengan struktur alur lengkap dan cerpen dengan struktur alur tidak } \\
\text { lengkap; (5) cerpen dengan alur progresif dan cerpen dengan alur sorot balik; (6) cerpen } \\
\text { dengan alur tunggal dan cerpen dengan alur paralel; ( } 7 \text { ) cerpen dengan alur padat dan } \\
\text { cerpen dengan alur longgar; dan (8) cerpen dengan alur peruntungan, cerpen dengan alur } \\
\text { tokohan, dan cerpen dengan alur pemikiran. }\end{array}$ \\
\hline
\end{tabular}

\section{PENDAHULUAN}

Menulis merupakan persoalan pilihan eksistensi, yaitu kesadaran untuk berproses secara aktifkreatif yang terus menerus (Kurniawan \& Sutardi, 2012:2). Proses kreatif seseorang dalam menuangkan gagasan dan perasaan yang dituangkan dalam sebuah bahasa tulis bertujuan agar pesan yang dikirimkan dipahami oleh pembaca dalam bentuk alat komunikasi secara tidak langsung(Andayani, Pratiwi, \& Priyatni, 2017). Salah satu bentuk hasil tulisan adalah cerpen. Dalam sebuah cerpen unsur tokoh dan alur enulisan menjadi salah satu bagian menarik untuk dikaji lebih jauh.

Tokoh merupakan salah satu unsur fiksional pembangun cerita yang dapat menunjukkan psikologis dan karakter manusia karena karya sastra cermin kehidupan. Sedangkan penokohan adalah cara pengarang menampilkan tokoh atau pelaku dalam cerita. Menurut Nurgiyantoro (2010:166-167), istilah penokohan lebih luas pengertiannya dari tokoh dan perwatakan sebab sekaligus mencakup masalah seputar penyikapan, perwatakan, penempatan dan pelukisannya dalam sebuah cerita sehingga sanggup memberikan gambaran yang jelas kepada pembaca. Hal ini disampaikan melalui deskripsi langsung pengarang dan melalui dialog-dialog tokoh itu sendiri atau dari tokoh lain. Tokoh cerita sebagai posisi strategis yang difungsikan sebagai pembawa dan penyampai pesan, amanat, moral, atau sesuatu yang sengaja ingin disampaikan kepada pembaca.

Cara menampilkan watak tokoh juga melalui dua cara. Cara tersebut yaitu dengan teknik langsung/analitik dan tidak langsung/dramatik. Teknik langsung yaitu teknik penggambaran watak tokoh dengan memaparkan secara langsung sifat tokoh. Teknik langsung ini mencakup teknik penggambaran tokoh melalui tuturan pengarang dan pelukisan fisik. Teknik tidak langsung yaitu penggambaran tokoh melalui pikiran, cakapan dan kelakuan tokoh yang menyiratkan watak tokoh. Teknik tidak langsung ini mencakup teknik penggambaran tokoh melalui penggunaan nama tokoh, penampilan tokoh, cakapan, tingkah laku, pikiran dan perasaan, arus kesadaran, reaksi tokoh, reaksi tokoh lain, dan pelukisan latar.

\footnotetext{
* Corresponding author.

E-mail addresses: helloichbinminerwa@yahoo.co.id (Mimin Ernawati)
}

ISSN : 2579-3799 (Online) - BASINDO : Jurnal Kajian Bahasa, Sastra Indonesia, dan Pembelajarannya is licensed under Creative Commons Attribution-ShareAlike 4.0 International License (http://creativecommons.org/licenses/BY/4.0/).

29 | BASINDO : Jurnal Kajian Bahasa, Sastra Indonesia, dan Pembelajarannya 
Alur merupakan sarana untuk memahami perjalanan kehidupan tokoh. Penokohan dan alur ini saling mempengaruhi. Kejadian, konflik, klimaks, peleraian hingga penyelesaian dalam sebuah cerita pasti ada pelaku cerita atau tokoh. Tokoh sekaligus penentu jalan cerita berikutnya karena alur terjadi karena ada perjalanan kehidupan tokoh baik cara berpikir dan berperasaan, bersikap, berperilaku, dan bertindak (Nurgiyantoro, 2010:173)

Kegiatan memahami tahapan-tahapan alur dianggap sebagai kegiatan yang sangat penting karena dalam setiap alur sebenarnya sudah terkandung semua unsur yang membentuk karya fiksi. Tahapan alur dibentuk oleh satuan-satuan peristiwa dan setiap peristiwa selalu diemban oleh pelaku-pelaku pembawa pesan dengan perwatakan tertentu, selalu memiliki latar tertentu, dan selalu menampilkan suasana tertentu pula. Sebab itulah, lewat pemahaman plot, pembaca sekaligus dapat juga berusaha memahami penokohan, perwatakan, maupun setting (Aminuddin, 2010:86-87). Lebih lanjut, Kurniawan dan Sutardi (2012:59) mengatakan bahwa kekuatan utama puisi ada pada diksi, kalimat, dan tipografi, sedangkan kekuatan cerita terdapat pada deskripsi peristiwa yang baik, yang merupakan perpaduan antara tokoh, latar, dan alur. Kedua pendapat tersebut menunjukkan bahwa alur mempunyai kedudukan tinggi dalam suatu cerpen. Selain itu, kemenarikan cerita dan pemahaman pembaca terhadap cerita juga tergantung pada penyajian alur.

Pemilihan mahasiswa sebagai subjek penelitian karena pada usia tersebut mahasiswa masuk dalam masa transisi dari remaja madya menuju remaja akhir sehingga perlu untuk diketahui kecenderungan karangan mahasiswa pada masa tersebut. Konopka (dalam Yusuf, 2001:184) menyebutkan bahwa masa remaja meliputi (1) remaja awal: 12-15 tahun; (2) remaja madya: 15-18 tahun, dan (3) remaja akhir: 19-22 tahun. Berdasarkan penjelasan tersebut diketahui bahwa mahasiswa masuk pada masa remaja akhir. Mahasiswa terkadang masih mengalami kesulitan dalam menulis cerita pendek. Kesulitan tersebut salah satunya adalah menuangkan dan mengolah ide. Mahasiswa pada umumnya selalu bingung dengan apa yang akan mereka tulis, bagaimana memulai tulisan, bagaimana mengaitkan setiap peristiwanya, bagaimana mengembangkan alurnya agar cerita lebih menarik, bagaimana mengaitkan perspektif mahasiswa dengan melihat sekitarnya, dan bagaimana mahasiswa dapat menjadikan karyanya sebagai salah satu sarana pendidikan karakter.

\section{METODE}

Penelitian ini menggunakan rancangan penelitian deskriptif kualitatif. Untuk menemukan kecenderungan penokohan dan pengaluran cerpen karya mahasiswa UM dalam majalah Komunikasi tahun terbit 2011-2017. Data yang digunakan merupakan kutipan dari narasi cerpen melalui prosedur pengumpulan data melalui dokumen. Sasaran utama peneliti adalah cerpen-cerpen yang dimuat dalam majalah Komunikasi tahun terbit 2011-2017.

Dalam penelitian ini yang menjadi instrumen penelitian adalah peneliti sendiri (human instrument) dengan dibantu oleh tabel pedoman analisis. Kedudukan peneliti (human instrument) dalam penelitian kualitatif sebagai perencana, pelaksana, pelapor hasil penelitiannya. Dalam penelitian ini, peneliti yang mengidentifikasi, mengklasifikasikan, dan menganalisis, serta menyimpulkan penokohan dan pengaluran pada teks cerpen mahasiswa. Hal tersebut dilakukan peneliti agar mencapai hasil penelitian yang komprehensif dan natural pada penokohan dan pengaluran pada teks cerpen mahasiswa. Instrumen tersebut dipilih disesuaikan berdasarkan wujud data (Arikunto, 2010:192; Moeleong, 2014:168).

Analisis data penelitian tentang penokohan dan pengaluran ini dilakukan dengan cara deskriptif karena menggambarkan apa adanya teknik pengembangan penokohan dan pengaluran pada teks cerpen. Analisis ini dilakukan tiga tahap yaitu (1) mereduksi data, (2) penyajian data, dan (3) penarikan kesimpulan dan verifikasi. Pertama,tahap mereduksi data berarti merangkum, memilih hal-hal yang pokok, memfokuskan pada hal-hal yang penting, dicari tema dan polanya, dan membuang yang tidak perlu (Sugiyono, 2012:338). Kedua, peneliti mengklasifikasikan data sesuai dengan fokus masalah yang ditentukan dan memasukkan ke dalam tabel analisis, Ketiga, kodifikasi yakni memberikan kode pada data untuk memudahkan dalam analisis data. Kode yang digunakan meliputi (1) menyebutkan aspek yang diteliti, (2) menyebutkan nomor urut cerpen, dan (3) menyebutkan nomor urut paragraf dalam cerpen.

Tahap penyajian data dilakukan dalam bentuk uraian singkat, bagan, hubungan antar kategori, flowchat, dan sejenisnya (Sugiyono, 2012:341). Tahap data display atau penyajian data dalam penelitian ini yaitu deskripsi. Peneliti mendeskripsikan data yang diperoleh sesuai dengan fokus penelitian yang telah ditentukan.

Tahap penarikan kesimpulan dan verifikasi dilakukan dengan mengecek hasil analisis data dengan kutipan yang diteliti sesuai dengan karakteristik penokohan dan alur. Kemudian, temuan dari hasil analisis data dibahas dalam bab pembahasan dengan didukung teori yang ada. 
Setelah dilakukan pendeskripsian analisis data, langkah lanjutan yang dilakukan peneliti adalah mengecek keabsahan temuan. Pengecekan keabsahan temuan dilakukan agar analisis dan interpretasi data dapat dipertanggungjawabkan. Pengecekan keabsahan temuan ini dilakukan dengan tiga cara, yaitu (1) ketekunan dan keajegan peneliti dengan membaca berulang-ulang secara cermat minimal tiga kali, (2) melakukan diskusi yaitu diskusi dengan teman sejawat yang berkompeten dengan bidang ini, dan (3) melakukan diskusi dengan ahli yaitu dosen pembimbing.

\section{HASIL}

Aspek kecenderungan penokohan berdasarkan paparan data, diperoleh penokohan secara langsung, tidak langsung, dan campuran. Kondisi yang menarik terkait paparan data aspek pengaluran, ditemukan tujuh belas variasi struktur pengembangan alur pada cerpen mahasiswa UM yang dimuat dalam majalah Komunikasi tahun terbit 2011-2017.

Kategori alur didasarkan pada urutan waktu, jumlah, kepadatan, dan isi. Dari keempat hal tersebut, terdapat sepuluh temuan. Pertama, cerpen dengan alur progresif atau alur maju. Tahapan-tahapan peristiwa dalam cerpen tersebut disajikan secara runtut dari pengenalan-konflik-komplikasi- klimaks-peleraianpenyelesaian, meskipun tidak semua dari cerpen memiliki tahapan yang lengkap.

Kedua, cerpen dengan alur regresif atau alur sorot balik. Tahapan- tahapan peristiwa dalam cerpen tersebut ada yang dimulai dari penyelesaian atau pun konflik, kemudian menceritakan peristiwa sebelumnya, setelah itu cerita kembali ke masa sekarang. Namun, tidak semua dari cerpen memiliki tahapan yang lengkap. Ketiga, cerpen dengan alur campuran. Tahapan-tahapan rangkaian peristiwa disajikan tidak selalu secara kronologis, dan secara garis besar berjalan progresif, tetapi didalamnya sering terdapat adegan-adegan sorot balik. Namun, tidak semua dari cerpen memiliki tahapan yang lengkap.

Keempat, cerpen dengan alur tunggal. Cerpen-cerpen tersebut hanya mengembangkan sebuah masalah dengan satu tokoh utama. Cerita tetap mempunyai tokoh tambahan lain, namun permasalahan mereka tetap merujuk pada tokoh utama. Kelima, cerpen dengan alur paralel. Cerpen-cerpen tersebut ditokohi oleh tokoh utama lain atau mempunyai dua tokoh yang sama penting dalam membangun latar.

Keenam, cerpen dengan alur padat. Cerpen-cerpen tersebut mempunyai rangkaian peristiwa yang susul-menyusul secara cepat. Hubungan antarperistiwa juga terjalin erat sehingga keutuhan cerita akan terganggu jika pembaca kehilangan salah satu peristiwa. Ketujuh, cerpen dengan alur longgar. Cerpencerpen tersebut mempunyai rangkaian peristiwa yang lambat. Hubungan antarperistiwa juga tidak terjalin begitu erat karena adanya penyisipan berbagai peristiwa lain.

Kedelapan, cerpen dengan alur peruntungan. Cerpen-cerpen tersebut menampilkan nasih atau peruntungan yang diperoleh tokoh utama, seperti sedih, tragis, dan bahagia. Kesembilan, cerpen dengan alur tokohan. Cerpen-cerpen tesebut lebih fokus menyoroti tokoh berserta keadaannya, seperti pendewasaan tokoh, dan pengujian terhadap tokoh. Kesepuluh, cerpen dengan alur pemikiran. Cerpen-cerpen tersebut mengungkapkan pemasalahan yang menjadi bahan pemikiran pembaca, seperti pembukaan rahasia.

\section{PEMBAHASAN}

\section{Teknik Penokohan secara Langsung atau Analitik}

Teknik penokohan secara langsung atau analitik menurut Nurgiyantoro (2010:195) adalah pelukisan tokoh cerita dilakukan dengan memberikan deskripsi, uraian atau penjelasan secara langsung. Tokoh cerita hadir dan dihadirkan oleh pengarang ke hadapan pembaca secara tidak berbelit-belit, melainkan begitu saja dan langsung disertai deskripsi kediriannya, yang mungkin berupa sikap, sifat, watak, tingkah laku, atau bahkan juga ciri fisiknya. Berdasarkan analisis 35 cerpen karya mahasiswa UM dalam majalah Komunikasi tahun terbit 2011-2017, teknik penokohan secara langsung atau analitik meliputi tuturan pengarang dan pelukisan fisik, dipaparkan sebagai berikut.

Pertama, tuturan pengarang dalam cerpen mahasiswa UM berupa perkenalan tentang nama tokoh, kebiasaan tokoh, kelebihan tokoh, hobi tokoh, prinsip hidup tokoh, dan sifat tokoh. Kenyataan tersebut sesuai dengan pendapat Nurgiyantoro (2010:195) bahwa teknik analitis ialah pelukisan tokoh cerita dilakukan dengan memberikan deskripsi, uraian, atau penjelasan secara langsung. Tokoh cerita hadir dan dihadirkan oleh pengarang kehadapan pembaca secara tidak berbelit-belit, melainkan begitu saja dan langsung disertai deskripsi kediriannya yang mungkin berupa sikap, sifat, watak, tingkah laku atau bahkan cirri fisiknya.

Kedua, pelukisan fisik dalam cerpen mahasiswa berupa pelukisan tentang postur tubuh tokoh dan warna kulit tokoh. Penulis sering membuat deskripsi mengenai bentuk tubuh, warna kulit, dan wajah tokohtokohnya. Dalam cerpen modern cara ini sudah jarang dipakai. Dalam fiksi lama penokohan fisik kerap kali dipakai untuk memperkuat watak (Saini, 1988:65). Memang benar apa yang dikatakan oleh Saini bahwa 
fiksi modern sudah jarang menggunakannya. Buktinya, cerpen mahasiswa jarang menggunakan pelukisan fisik tokoh.

\section{Teknik Penokohan secara Tidak Langsung atau Dramatik}

Teknik penokohan tokoh secara tidak langsung atau dramatik menurut Dermawan (1996:94) penokohan watak tokoh melalui pikiran, cakapan, dan lakuan para tokoh itu sendiri, bahkan juga dari penampilan fisiknya serta dari gambaran lingkungan atau latar cerita. Berdasarkan hasil analisis terhadap 35 cerpen karya mahasiswa UM dalam majalah Komunikasi tahun terbit 2011-2017, teknik penokohan tokoh secara tidak langsung meliputi penggunaan nama tokoh, penampilan tokoh, cakapan, tingkah laku, pikiran dan perasaan, arus kesadaran, reaksi tokoh, reaksi tokoh lain, dan pelukisan latar.

Pertama, penggunaan nama tokoh dalam cerpen karya mahasiswa ini selalu ada. Setiap cerpen ada nama tokoh. Nama dalam cerpen penting karena nama merupakan sebuah tanda yang berarti, seperti yang diungkapkan oleh Sugiharto (2008:8) bahwa nama dalam fiksi adalah tanda. Maka, sebenarnya ia juga memiliki makna. Nama tokoh yang digunakan oleh mahasiswa ada yang sesuai antara arti nama dengan watak tokoh dan ada yang tidak sesuai antara arti nama dengan watak tokoh di dalam cerita. Nama yang digunakan ada juga yang menunjukkan latar belakang budaya khususnya budaya Jawa yaitu penggunaan nama Prayoga dan Soke Ninik. Hal ini sesuai dengan apa yang diungkapkan oleh Sahid Teguh Widodo (dalam Kosasih, 2010:2) bahwa Strategic View, yaitu aspek strategis dari akumulasi fenomerna, termasuk segala bentuk perubahan dan perkembangannya, dan jauh lebih mengenai hubungan kebudayaan dengan bahasa, khususnya dalam nama sendiri.

Kedua, penampilan tokoh yang digunakan mahasiswa dalam menggambarkan watak tokoh berupa pakaian yang digunakan tokoh untuk memperjelas kondisi tokoh dan untuk memperjelas usia tokoh, menunjukkan kondisi tokoh, menunjukkan adanya perubahan fisik karena perubahan usia, dan menunjukkan apa yang digunakan untuk mendukung kondisi tokoh atau asesoris tokoh untuk pelengkap saja atau menunjukkan gaya hidup. Cara yang dituliskan oleh mahasiswa dalam menggambarkan watak tokoh sesuai dengan pendapat Minderop (2011:12) bahwa rincian penampilan memperlihatkan kepada pembaca tentang usia, kondisi fisik/kesehatan dan tingkat kesejahteraan tokoh. Dari pelukisan ini tampak apakah si tokoh merupakan sosok yang kuat, terkadang lemah, relatif berbahagia, tenang atau kadangkala kasar.

Ketiga, teknik menggambarkan tokoh dengan cakapan. Cakapan tersebut berupa cakapan biasa tanpa ada aksi ataupun reaksi, cakapan yang disertai dengan tindakan atau tingkah laku, dan cakapan wujud dari reaksi tokoh.

Cakapan ada di setiap cerpen dan banyak digunakan karena cara ini mudah dan menyesuaikan dengan kondisi pembaca majalah Komunikasi secara umum. Selain itu, mahasiswa sebagian besar membaca cerpen dan novel yang banyak cakapannya sehingga mahasiswa dalam menulis juga banyak menggunakan cakapan dalam menggambarkan watak tokoh. Cakapan banyak digunakan seperti yang diungkapkan Nurgiyantoro (2010:201) bahwa bentuk cakapan dalam karya fiksi khususnya novel umumnya cukup banyak, baik percakapan yang pendek maupun yang agak panjang.

Keempat, cara menggambarkan watak tokoh dengan tingkah laku dalam cerpen karya mahasiswa berupa tingkah laku yang menunjukkan gaya hidup tokoh, tingkah laku karena sifat yang dimiliki, dan tingkah laku karena wujud reaksi dari tokoh. Teknik tingkah laku menyaran pada tindakan yang bersifat nonverbal, fisik, yang dilakukan orang dalam wujud tindakan dan tingkah laku, dalam banyak dapat dipandang sebagai menunjukkan reaksi, tanggapan, sifat, dan sikap yan mencerminkan sifat-sifat kediriannya (Nurgiyantoro, 2010:203).

Kelima, teknik pikiran dan perasaan yang menunjukkan sifat banyak digunakan mahasiswa. Pikiran dalam cerpen berupa pikiran yang positif dan negatif, sedangkan perasaan berupa perasaan senang, optimis, cemas, khawatir, rindu, kesepian, tidak percaya diri, dan percaya diri. Pikiran dan perasaan yang dialami tokoh juga menunjukkan wujud reaksi tokoh terhadap suatu hal. Hal tersebut sesuai dengan pernyataan Nurgiyantoro (2010:204) bahwa jalan pikiran serta perasaan, yang melintas di dalam pikiran dan perasaan, serta yang sering dipikir serta dirasakan oleh tokoh, dalam banyak hal akan mencerminkan sifat- sifat kediriannya juga.

Keenam, arus kesadaran dalam cerpen mahasiswa berupa monolog batin tokoh karena beban hidup, karena penyesalan, emosi, dan harapan. Arus kesadaran dalam cerpen mahasiswa sangat jarang digunakan karena arus kesadaran ini cukup sulit. Menurut Nurgiyantoro (2010:206) penggunaan teknik arus kesadaran, monolog batin itu, dalam penokohan dapat dianggap sebagai usaha untuk mengungkapkan informasi yang sebenarnya tentang kedirian tokoh karena tidak sekedar menunjukkan tingkah laku yang dapat diindera saja. Menurut Wiyatmi (2013:33) arus kesadaran merupakan cara penceritaan untuk menangkap dan melukiskan warna-warni perkembangan karakter, yakni ketika persepsi 
bercampur dengan kesadaran atau setengah kesadaran dengan kenangan dan perasaan. Jadi memang benar apa yang digambarkan oleh penulis menunjukkan tingkah laku tokoh yang tidak bisa diindera dan merupakan pencampuran perasaan dan kenangan.

Ketujuh, reaksi tokoh dalam cerpen karya mahasiswa ini berupa tingkah laku atau tindakan, reaksi tokoh yang berupa perasaan tokoh, dan reaksi tokoh berupa kondisi ataupun keadaan tokoh saat menghadapi suatu hal. Reaksi tokoh menurut Nurgiyantoro (2010:208) adalah reaksi tokoh terhadap suatu kejadian, masalah, keadaan, kata, dan sikap tingkah laku orang lain, dan sebagainya yang berupa rangsang dari luar tokoh yang bersangkutan. Bagaimana reaksi tokoh terhadap hal-hal tersebut dapat dipandang sebagai suatu bentuk penampilan yang mencerminkan sifat-sifat kediriannya. Sesuai dengan pendapat Nurgiyantoro yang sudah digambarkan oleh siswa menunjukkan reaksi dari tokoh mengenai suatu hal.

Kedelapan, reaksi tokoh lain dalam cerpen karya mahasiswa ini berupa reaksi tokoh lain terhadap tokoh lain tentang kebaikannya atau sisi positif tokoh dan ada reaksi tentang sisi keburukannya atau sisi negatif tokoh. Menurut Nurgiyantoro (2010:209) reaksi tokoh lain dimaksudkan sebagai reaksi yang diberikan oleh tokoh lain terhadap tokoh utama. Atau tokoh yang dipelajari kediriannya, yang berupa pandangan, pendapat, sikap, komentar, dan lain-lain. Reaksi tokoh lain merupakan teknik penokohan untuk mengingformasikan kedirian tokoh kepada pembaca. Sesuai dengan pendapat Nurgiyantoro (2010:209) reaksi tokoh lain dalam cerpen siswa menunjukkan komentar tokoh lain terhadap tokoh utama baik dari sisi positif tokoh maupun sisi negatif tokoh.

Kesembilan, teknik penokohan tokoh dengan pelukisan latar berupa pelukisan latar tokoh yang kumuh, bersih, dan latar yang mengandung seni. Menurut Nurgiyantoro (2010:209) bahwa pelukisan latar sering mengintensifkan sifat kediriannya. Pelukisan suasana latar dapat lebih mengintensifkan sifat kedirian tokoh. Seperti yang diungkapkan oleh Nurgiyantoro (2010:210) pelukisan latar oleh penulis untuk mendukung tentang tokoh saja.

\section{Penggabungan Teknik Penokohan Tokoh secara Langsung dan Tidak Langsung}

Penggabungan teknik penokohan tokoh secara langsung dan tidak langsung oleh mahasiswa dalam menulis cerpen dapat ditemukan variasi penggunaan sebagai berikut (1) tuturan pengarang, penggunaan nama tokoh, cakapan, tingkah laku, arus kesadaran, dan reaksi tokoh, (2) tuturan pengarang, penggunaan nama tokoh, penampilanm tokoh, cakapan, tingkah laku, pikiran dan perasaan, arus kesadaran, reaksi tokoh, dan pelukisan latar, (3) tuturan pengarang, penggunaan nama tokoh, penampilan tokoh, cakapan, pikiran dan perasaan, reaksi tokoh, (4) tuturan pengarang, penggunaan nama tokoh, penampilan tokoh, cakapan, tingkah laku, dan reaksi tokoh, (5) tuturan pengarang, penggunaan nama tokoh, cakapan, tingkah laku, dan pikiran dan perasaan, (6) tuturan pengarang, penggunaan nama tokoh, cakapan, tingkah laku, dan reaksi tokoh lain, (7) tuturan pengarang, pelukisan fisik, penggunaan nama tokoh, penampilan tokoh, cakapan, tingkah laku, dan reaksi tokoh lain, (8) tuturan pengarang, penggunaan nama tokoh, cakapan, tingkah laku, reaksi tokoh, dan pelukisan latar, (9) tuturan pengarang, penggunaan nama tokoh, cakapan, tingkah laku, dan reaksi tokoh, (10) tuturan pengarang, penggunaan nama tokoh, penampilan tokoh, dan cakapan, (11) tuturan pengarang, pelukisan fisik, penggunaan nama tokoh, penampilan tokoh, cakapan, tingkah laku, pikiran dan perasaan, arus kesadaran, dan reaksi tokoh, (12) tuturan pengarang, pelukisan fisik, penggunaan nama tokoh, penampilan tokoh, cakapan, tingkah laku, pikiran dan perasaan, dan pelukisan latar, (13) penggunaan nama tokoh, cakapan, dan pikiran dan perasaan, (14) tuturan pengarang, penggunaan nama tokoh, cakapan, tingkah laku, dan pikiran dan perasaan, (15) tuturan pengarang, pelukisan fisik, penggunaan nama tokoh, penampilan tokoh, cakapan, pikiran dan perasaan, reaksi tokoh lain, dan pelukisan latar, (16) tuturan pengarang, penggunaan nama tokoh, cakapan, dan pikiran dan perasaan, (17) tuturan pengarang, penggunaan nama tokoh, penampilan tokoh, cakapan, tingkah laku, pikiran dan perasaan, dan reaksi tokoh, (18) tuturan pengarang, penggunaan nama tokoh, cakapan, tingkah laku, pikiran dan perasaan, arus kesadaran, reaksi tokoh, dan reaksi tokoh lain, (19) tuturan pengarang, penggunaan nama tokoh, cakapan, pikiran dan perasaan, reaksi tokoh lain, dan pelukisan latar, (20) tuturan pengarang, penggunaan nama tokoh, penampilan tokoh, cakapan, pikiran dan perasaan, reaksi tokoh lain, dan pelukisan latar, (21) tuturan pengarang, penggunaan nama tokoh, dan cakapan, (22) penggunaan nama tokoh, penampilan tokoh, cakapan, pikiran dan perasaan, dan reaksi tokoh lain, (23) tuturan pengarang, pelukisan fisik, penggunaan nama tokoh, cakapan, tingkah laku, dan pikiran dan perasaan.

Variasi penggunaan dalam cerpen mahasiswa menunjukkan bahwa mahasiswa kreatif dan variatif dalam menggunakan teknik penokohan. Penggabungan teknik penokohan oleh mahasiswa di dalam cerpennya sesuai dengan pendapat Nurgiyantoro (2010:195) pada umumnya pengarang memilih cara 
campuran, mempergunakan teknik langsung dan tidak langsung dalam sebuah karya. Hal itu dirasa lebih menguntungkan karena kelemahan masing- masing teknik dapat ditutup dengan teknik yang lain.

Penggabungan cara penokohan tokoh secara langsung dengan tidak langsung sesuai dengan hasil penelitian yang dilakukan oleh Nurhidayati (2011:248) terhadap karakteristik narasi karya mahasiswa Sastra Arab, bahwa tokoh dilukiskan dengan teknik pelukisan tokoh langsung dan pelukisan tokoh tak langsung. Hal ini menunjukkan bahwa penulis sudah memvariasikan metode pelukisan tokoh.

Teknik penokohan tokoh secara langsung berfungsi untuk mendukung alur bagian perkenalan tentang tokoh, penyelesaian, dan untuk memperkuat atau memperjelas karakter tokoh. Hal ini sesuai dengan apa yang dikatakan oleh Nurgiyantoro (2010:195) bahwa informasi tentang kedirian tokoh biasanya terdapat pada tahap perkenalan.

Teknik penokohan tokoh secara tidak langsung berfungsi untuk mendukung alur bagian perkenalan, konflik, konflik batin, dan penyelesaian. Mendukung latar suasana dan memperjelas atau memperkuat karatker tokoh. Penampilan tokoh digunakan untuk memperjelas dan mendukung tentang kedirian tokoh. Hal ini sesuai dengan pendapat Minderop (2011:12) cara berpakaian para tokoh dengan tujuan memperjelas dan mempertajam watak tokoh. Dialog dapat mengembangkan peristiwa-peristiwa dalam suatu alur atau sebaliknya (Minderop,

2011:21). Hal tersebut sesuai dengan yang diungkapkan oleh Nurgiyantoro (2010:201) bahwa percakapan yang baik, yang efektif, yang lebih fungsional, adalah yang menunjukkan perkembangan plot dan sekaligus mencerminkan sifat kedirian tokoh pelakunya.

\section{Struktur Pengaluran}

Cerpen karya mahasiswaUM dalam majalah Komunikasi tahun terbit 2011-2017 dengan struktur alur lengkap ada 28 cerpen. Struktur alur lengkap yang ada dalam cerpen tersebut adalah pengenalan, konflik, komplikasi, klimaks, peleraian, dan penyelesaian. Selain itu, ada beberapa cerpen yang struktur alurnya terjadi dua dan tiga kali.

Mahasiswa menggunakan dua macam penyelesaian untuk mengakhiri cerita, yaitu penyelesaian terbuka dan tertutup. Namun, mayoritas mahasiswa lebih menggunakan penyelesaian tertutup karena mereka sendirilah yang mengakhiri jalannya cerita sebanyak 31 judul cerpen, dan hanya ada 4 judul cerpen yang menggunakan penyelesaian terbuka atau menyerahkan akhir cerita kepada pembaca. Hal tersebut sesuai dengan pendapat Siswanto (2008:160) yang mengemukakan bahwa ada dua macam selesaian, yaitu tertutup dan terbuka. Selesaian tertutup adalah bentuk penyelesaian cerita yang diberikan oleh sastrawan. Selesaian terbuka adalah bentuk penyelesaian cerita yang diserahkan kepada pembaca.

Cerpen karya mahasiswaUM dalam majalah Komunikasi tahun terbit 2011-2017 dengan struktur alur tidak lengkap ada 7. Ketidaklengkapan tahap terjadi karena ada salah satu tahap atau lebih yang tidak terdapat dalam cerpen. Ketidaklengkapan tahap tersebut merupakan hal yangwajar karena cerpen tidak harus mempunyai struktur alur yang lengkap. Hal ini sesuai dengan pendapat Siswanto (2008: 160) yang menyatakan bahwa dalam cerita lama, alur dimulai dari pengenalan, konflik, komplikasi, klimaks, peleraian, dan diakhiri dengan tahap penyelesaian, tetapi tidak semua cerita mempunyai seluruh tahap alur tersebut.

Ketidaklengkapan struktur alur tidak berlaku untuk tahap konflik dan pengenalan. Meskipun ada salah satu atau lebih struktur alur yang tidak dihadirkan, konflik tetap dihadirkan oleh mahasiswa. Hal ini karena konflik mempunyai kedudukan penting dalam sebuah cerita. Tanpa adanya konflik, cerita akan terasa hambar dan kurang menarik yang kemungkinan tidak akan menimbulkan berbagai pemikiran kepada pembaca. Hal ini sesuai dengan pendapat Nurhadi dkk (2004:120) yang mengungkapkan bahwa pengembangan kisah dalam cerpen bertumpu pada pengembangan masalah atau konflik yang dihadapi para tokoh. Mahasiswa juga selalu menghadirkan tahap pengenalan dalam ceritanya. Tahap pengenalan penting untuk dihadirkan dalam setiap cerita supaya pembaca dapat mengenali tokoh dan situasi awal. Hal ini sesuai dengan pendapat yang dikemukakan oleh Nurgiyantoto (2013:203) bahwa pada dasarnya setiap adegan cerita membutuhkan pembukaan baik berada di awal maupun di tengah cerita.

Setiap cerita mempunyai struktur alur yang berbeda. Namun, semua alur cerita sudah tentu mengandung unsur urutan waktu. Tidak semua alur berjalan secara kronologis dimulai dari awal. Ada alur yang dimulai dari bagian tengah atau konflik, ada juga yang dimulai dari bagian akhir. Sebagaimana dikemukakan oleh Siswanto (2008:160) bahwa untuk cerita modern, alur tidak selalu dimulai dari pengenalan dan diakhiri tahap penyelesaian.

Panjang-pendeknya suatu cerita ternyata memengaruhi struktur alur. Cerpen yang ditulis lebih panjang mempunyai peristiwa lebih banyak sehingga sangat memungkinkan satu tahap alur atau lebih terjadi dua kali, misalnya konflik yang terjadi dua kali dalam satu cerpen. Cerpen yang ditulis pendek cenderung 
mempunyai peristiwa yang terbatas sehingga memungkinkan tidak adanya tahap alur yang terjadi dua kali, bahkan bisa jadi tahap alurnya tidak lengkap.Berdasarkan hasil tersebut, pada kelengkapanstruktur alur mahasiswa cenderung menggunakan struktur alur lengkap meskipun ada tahapan yang terjadi dua hingga tiga kali.

\section{Kategori Pengaluran}

Cerpen karya mahasiswa UM dalam majalah Komunikasi tahun terbit 2011-2017 dengan jenis alur progresif ada 14. Tahapan-tahapan peristiwa dalam cerpen tersebut disajikan secara runtut dari awal menuju akhir atau pengenalan- konflik-komplikasi-klimaks-peleraian-penyelesaian, meskipun tidak semua dari cerpen memikii tahapan yang lengkap. Hal ini sesuai dengan yang dikemukakan oleh Nurgiyantoro (2013:213) bahwa alur dikatakan progresif jika cerita secara runtut dimulai dari tahap awal (penyituasian, pengenalan, pemunculan konflik), tengah (konflik meningkat, klimaks) dan akhir (penyelesaian).

Cerpen karya mahasiswa UM dalam majalah Komunikasi tahun terbit 2011-2017 dengan jenis alur regresif ada 8. Tahapan-tahapan peristiwa dalam cerpen tersebut ada yang dimulai dari penyelesaian atau pun konflik, kemudian menceritakan peristiwa sebelumnya, setelah itu cerita kembali ke masa sekarang. Namun, tidak semua dari cerpen memiliki tahapan yang lengkap. Hal ini sesuai dengan pendapat Nurgiyantoro (2013:214) yang mengungkapkan bahwa urutan kejadian yang dikisahkan dalam cerita fiksi yang berplot sorot balik tidak bersifat kronologis.

Cerpen karya mahasiswa UM dalam majalah Komunikasi tahun terbit 2011-2017 dengan jenis alur campuran ada 13. Tahapan-tahapan rangkaian peristiwa disajikan tidak selalu secara kronologis, dan secara garis besar berjalan progresif, tetapi didalamnya sering terdapat adegan-adegan sorot balik. Namun, tidak semua dari cerpen memiliki tahapan yang lengkap. Hal ini sesuai dengan pendapat Nurgiyantoro (2010:215) mengungkapkan bahwa cerita yang beralur campuran secara garis besar berjalan progresif, tetapi di dalamnya sering terdapat adegan-adegan sorot balik. Berdasarkan hasil tersebut, pada kategori alur berdasarkan urutan waktu, tidak semua cerpen diawali dari tahap pengenalan, dan tidak semua cerpen memiliki tahapan alur yang lengkap. Mahasiswa cenderung menggunakan alur progresif dalam mengembangkan cerita.

Cerpen karya mahasiswa UM dalam majalah Komunikasi tahun terbit 2011-2017 dengan jenis alur tunggal ada 23. Cerpen-cerpen tersebut hanya mengembangkan sebuah masalah dengan satu tokoh utama. Cerita tetap mempunyai tokoh tambahan lain, namun permasalahan mereka tetap merujuk pada tokoh utama. Hal ini sesuai dengan yang diungkapkan Nurgiyantoro (2013:217) bahwa karya fiksi yang beralur tunggal biasanya hanya mengembangkan sebuah cerita dengan menampilkan seorang tokoh utama protagonis yang sebagai hero.

Cerpen karya mahasiswa UM dalam majalah Komunikasi tahun terbit 2011-2017 dengan jenis alur paralel ada 12. Cerpen-cerpen tersebut mengembangkan beberapa peristiwa dan ditokohi oleh tokoh utama lain atau mempunyai dua tokoh yang sama penting dalam membangun alur. Hal ini sesuai dengan yang dikemukakan oleh Nurgiyantoro (2013:218) bahwa alur parallel biasanya ditokohi oleh tokoh utama lain (protagonis ataupun antagonis) dan cukup tinggi kadar pentingnya dalam membangun plot secara keseluruhan dan karenanya perlu diperhitungkan dalam pembuatan sinopsis. Berdasarkan hasil tersebut, pada kategori alur berdasarkan jumlah tokoh dan peristiwa, mahasiswa cenderung menggunakan alur tunggal dalam mengembangkan cerita.

Cerpen karya mahasiswa UM dalam majalah Komunikasi tahun terbit 2011-2017 dengan jenis alur padat ada 23. Cerpen-cerpen tersebut mempunyai rangkaian peristiwa yang susul-menyusulnya secara cepat. Hubungan antarperistiwa juga terjalin erat sehingga keutuhan cerita akan terganggu jika pembaca kehilangan salah satu peristiwa. Hal ini sesuai dengan pendapat Nurgiyantoro (2013:219) yang menyatakan bahwa dalam alur padat, cerita disajikan secara cepat, dan hubungan antarperistiwa juga terjalin secara erat.

Cerpen karya mahasiswa UM dalam majalah Komunikasi tahun terbit 2011-2017 dengan jenis alur longgar ada 12. Cerpen-cerpen tersebut mempunyai rangkaian peristiwa yang lambat. Hubungan antarperistiwa juga tidak terjalin begitu erat karena adanya penyisipan berbagai peristiwa lain. Hal ini sesuai dengan yang diungkapkan Nurgiyantoro (2013:221) bahwa antaraperistiwa penting yang satu dengan yang lain sering disisipi oleh berbagai peristiwa tambahan, atau berbagai pelukisan tertentu seperti penyituasian latar dan suasana, yang dapat memperlambat ketegangan cerita. Berdasarkan hasil tersebut, pada kategori alur berdasarkan kepadatan peristiwa, mahasiswa cenderung menggunakan alur padat dalam mengembangkan cerita.

Cerpen karya mahasiswa UM dalam majalah Komunikasi tahun terbit 2011-2017 dengan jenis alur peruntungan ada 16 . Cerpen-cerpen tersebut menampilkan nasib atau peruntungan yang diperoleh 
tokoh utama, yaitu sedih, tragis, dan bahagia. Hal ini sesuai dengan pendapat Nurgiyantoro (2013:222) yang menyatakan bahwa alur peruntungan berhubungan dengan cerita yang mengungkapkan nasib atau peruntungan yang menimpa tokoh (utama) cerita pada sebuah cerita fiksi.

Cerpen karya mahasiswa UM dalam majalah Komunikasi tahun terbit 2011-2017 dengan jenis alur tokohan ada 15. Cerpen-cepen tersebut lebih fokus menyoroti tokoh beserta keadaannya, yaitu pendewasaan dan pengujian terhadap tokoh. Hal ini sesuai dengan yang dikatakan oleh Nurgiyantoro (2013:222) bahwa alur tokohan lebih banyak menyoroti keadaan tokoh dari pada kejadian-kejadian yang ada atau yang berurusan dengan pemlotan.

Cerpen karya mahasiswa UM dalam majalah Komunikasi tahun terbit 2011-2017 dengan jenis alur pemikiran ada 4. Cerpen-cerpen tersebut mengungkapkan permasalahan yang menjadi bahan pemikiran pembaca, yaitu pembukaan rahasia. Hal ini sesuai dengan yang diungkapkan Nurgiyantoro (2013:223) bahwa alur pemikiran mengungkapkan sesuatu yang menjadi bahan pemikiran, keinginan, perasaan, berbagai macam obsesi yang menjadi masalah hidup dan kehidupan manusia. Berdasarkan hasil tersebut, pada kategori alur berdasarkan isi cerita, mahasiswa lebih cenderung menggunakan alur peruntungan dalam mengembangkan cerita.

\section{SIMPULAN}

Berdasarkan hasil paparan data dan temuan data serta pembahasan terkait teknik penokohan dan pengaluran pada cerpen karya mahasiswa UM dalam majalah Komunikasi tahun terbit 2011-2017, disimpulkan empat hal. Simpulan ini berdasarkan fokus penelitian.

Pertama, teknik penokohan tokoh secara langsung atau analitik dalam cerpen yang paling banyak digunakan adalah tuturan pengarang. Pada semua cerpen terdapat tuturan pengarang dalam menggambarkan watak tokoh hanya dua cerpen yang tidak menggunakan tuturan pengarang dalam menggambarkan watak tokoh. Dengan demikian penokohan tokoh langsung dari tuturan pengarang teknik analitik yang dominan.

Kedua, teknik penokohan tokoh secara tidak langsung dalam cerpen siswa yang paling banyak digunakan adalah cakapan. Cakapan ada di setiap cerpen karya mahasiswa UM dalam majalah Komunikasi tahun terbit 2011-2017. Dengan demikian cakapan merupakan teknik penokohan tokoh secara tidak langsung yang dominan.

Ketiga, fungsi teknik penokohan tokoh secara langsung oleh siswa untuk mendukung alur bagian perkenalan, penyelesaian, dan untuk memperkuat atau memperjelas tentang karakter tokoh. Fungsi teknik penokohan tokoh secara tidak langsung untuk mendukung alur bagian perkenalan, konflik, konflik batin, dan penyelesaian. Mendukung latar suasana dan memperjelas atau memperkuat tentang karakter tokoh.

Terdapat bermacam-macam struktur dan kategori alur yang digunakan oleh mahasiswa UM dalam majalah Komunikasi tahun terbit 2011-2017 yang diuraikan sebagai berikut. Pertama, pada kelengkapan struktur alur mahasiswa cenderung menggunakan struktur alur lengkap meskipun ada tahapan yang terjadi dua hingga tiga kali. Struktur alur yang cenderung digunakan mahasiswa adalah pengenalan-konflik-komplikasi-klimaks-peleraian-penyelesaian.

Kedua, pada ketegori alur berdasarkan urutan waktu, tidak semua cerpen diawali dari tahap pengenalan dan tidak semua cerpen memiliki struktur alur yang lengkap. Mahasiswa cenderung menggunakan alur progresif dalam mengembangkan cerita. Ketiga, pada kategori alur berdasarkan jumlah tokoh dan peristiwa, mahasiswa cenderung menggunakan alur tunggal. Keempat, pada kategori alur berdasarkan kepadatan peristiwa, mahasiswa cenderung menggunakan alur padat dalam mengembangkan cerita. Kelima, pada ketegori alur berdasarkan isi cerita, mahasiswa lebih cenderung menggunakan alur peruntungan dalam mengembangkan cerita.

\section{SARAN}

Bagi mahasiswa disarankan untuk lebih banyak membaca cerpen sehingga pengetahuam tentang cara menggambarkan watak tokoh dan mengembangkan alur cerita semakin banyak dan variatif.

Bagi dosen disarankan menerapkan hasil penelitian ini dalam pembelajaran menulis cerpen. Dosen dapat memberikan penjelasan tentang teknik-teknik yang bisa digunakan dalam menggambarkan watak tokoh dan mengembangkan alur cerita sehingga mahasiswa memiliki banyak wawasan terkait teknik penokohan dan pengaluran sebuah karya fiksi.

Bagi peneliti lain disarankan melakukan penelitian yang bersifat meningkatkan kualitas cerpen berdasarkan teknik penokohan dan pengaluran. Peneliti lain juga disarankan untuk melakukan penelitian teknik dan fungsi penokohan, serta struktur dan kategori pengaluran secara lebih mendalam lagi. 


\section{DAFTAR RUJUKAN}

Andayani, R., Pratiwi, Y., \& Priyatni, E. T. (2017). Pengembangan Modul Pembelajaran Menulis Cerpen Bermuatan Motivasi Berprestasi Untuk Siswa Kelas Xi Sma. BASINDO : Jurnal Kajian Bahasa, Sastra Indonesia, Dan Pembelajarannya, 1(1), 103-116.

Aminuddin, 2010. Pengantar Apresiasi Karya Sastra. Bandung: Sinar Baru Algensindo. Arikunto, S. 2010. Prosedur Penelitian: Suatu Pendekatan Praktik. Jakarta: Rineka Cipta.

Dermawan, T. 1996. Apresiasi Prosa Fiksi. Malang: UM Press.

Dewi, D. A. C. 2013. Karakteristik Cerpen pada Lomba Menulis Cerpen Siswa SMA se-Kota Malang. Skripsi tidak diterbitkan. Malang: Fakultas Sastra Universitas Negeri Malang.

Kosasih, D. 2010. Kosmologi Sistem Nama Diri (antroponim) Masyarakat Sunda. Makalah disajikan pada Seminar Internasional "Hari Bahasa Ibu", (Online), diakses 19 April 2016.

Kurniawan, H. \& Sutardi. 2012. Penulisan Sastra Kreatif. Yogyakarta: Graha Ilmu.

Minderop, A. 2011. Metode Karakterisasi Telaah Fiksi. Jakarta: Yayasan Pustaka Obor Indonesia.

Moeleong, Lexy J. 2014. Metodologi Penelitian KualitatifEdisi Revisi. Bandung: Remaja Rosda Karya.

Nazir, M. 2005. Metode Penelitian. Bogor: Ghalia Indonesia. Nurgiyantoro, B. 2010. Teori Pengkajian Fiksi. Yogyakarta: Gadjah Mada University Press.

Nurhadi. 2012. Menulis 20 Ragam Tulisan. Malang: Universitas Negeri Malang. Sayuti, A.S. 2000. Berkenalan dengan Prosa Fiksi. Yogyakarta: Gama Media.

Shollikhah, K.F. 2012. Kecenderungan Unsur Fiksional Cerita Pendek Anak 2000-an. Skripsi tidak diterbitkan. Malang: Fakultas Sastra Universitas Negeri Malang.

Siswanto, W. 2008. Pengantar Teori Sastra. Jakarta: Grasindo.

Siswanto, W. (Muakibatul \& Djoko, Ed.). 2014. Cara Menulis Cerita. Malang: Aditya Media.

Sumardjo, J. 2004. Seluk Beluk dan Petunjuk Menulis Cerita Pendek. Bandung: Pustaka Latifah.

Suroto. 1989. Apresiasi Sastra Indonesia untuk SMU. Jakarta: Erlangga.

Tarigan, H.G. 1984. Prinsip-prinsip Dasar Sastra. Bandung: Angkasa.

Wiyatmi. 2006. Pengantar Kajian Sastra. Yogyakarta: Pustaka.

Yusuf, S. 2001. Psikologi Perkembangan Anak dan Remaja. Bandung: Remaja Rosdakarya. 